\title{
Explaining the Aspects of Resistance Economy Based on Knowledge- based Economy in University of Medical Sciences: The Viewpoints of Managers and Faculty Members
}

\author{
Shima Kazemi Malek Mahmoudi ${ }^{1}$, Kiomars Niaz Azari ${ }^{* 2}$, Negin Jabari ${ }^{1}$ \\ 1. Department of Management, Gorgan Branch, Islamic Azad University, Gorgan, Iran \\ 2. Department of Management, Sari Branch, Islamic Azad University, Sari, Iran
}

Article Type:

Original Article

Article History:

Received: 16 Sep 2017

Revised: 7 May 2018

Accepted: 3 Jun 2018

\section{*Correspondence:}

Kiomars Niaz Azari, Department of

Management, Sari

Branch, Islamic Azad

University, Sari, Iran

k.niazazari@,gmail.com

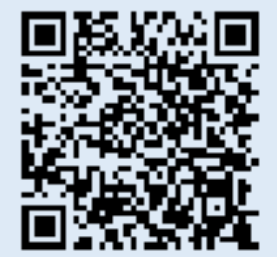

\begin{abstract}
Background and objectives: Knowledge-based economy is one of the major parts of the resistance economy and is recognized as the essentials of the information technology age. The managers and faculty members play an important role in this regard. This study aimed to explain the dimensions of the resistance economy based on the knowledgebased economy in universities of medical sciences.
\end{abstract}

Methods: This qualitative research had a purposeful sampling method. Data were collected via library and field research. In the library method, the relevant specialized scientific texts and resources were exploited, whereas in the fieldwork, the researcher interviewed 24 faculty members. After that, the interviews were analyzed. In the field method, the texts and books were evaluated and information searched in scientific and specialized websites. In the field research and after coordination with faculty members and main elites with a history of article or innovation production or a management background, the opinions of the interviewees were asked about some questions in a semistructured manner. In addition, three-stage coding, open coding, axial coding, and selective coding were applied in the research. To perform open coding, the main sentences were recorded as codes, followed by classifying the similar codes. In axial coding, the classes were related to their subclasses by comparing the primary classes of open coding and revolving the ones that resembled around the common axis. In selective coding, the integration and refining process of the categories was performed to form and present the model, and the dimensions were extracted and explained.

Results: From the perspective of the faculty members and key experts, resistance economy based on knowledge-based economy in universities of medical sciences could be explained in dimensions of information and communications technology, innovation and entrepreneurship in medical sciences, human resources and knowledge-based team, administrative and structural system, resources of equipment and abilities, policy and socio-environmental impacts. Each of these dimensions also included sub-groups and special themes.

Conclusion: Moving towards the knowledge-based economy is one of the requirements of the country on the path to economic development, which involves dimensions such as information and communications technology, innovation and entrepreneurship, strategic planning and policy-making, formulating and ensuring the legal framework and legal system, supplying and developing electronic infrastructures, and paying attention to capabilities and resources of facilities.

Keywords: Dimensions of Resistance Economy, Knowledge-based Economy, University of Medical Sciences

Copyright $($ 2018, Jorjani Biomedicine Journal has published this work as an open access article under the terms of the Creative Commons Attribution License (http://creativecommons.org/licenses/by-nc/4.0/) which permits noncommercial uses of the work while it is properly cited. 


\section{Introduction}

Today, the world has entered a new stage where the product-based economy has been quickly replaced by the knowledge-based economy. In this novel strategy, achieving innovation and using opportunities for success and growth is of paramount importance, in a way that knowledge production and use have played a central role in the process of wealth creation worldwide (1). This new economy which has more mastery due to global penetration and speed through information and communication, regardless of distance dimension, can solve the economic problems and pressures in the countries (2).

Over the past years, restrictions such as domestic business and external communications have been created in Iran due to stronger economic sanctions, economic conditions and depression, and the psychological and economic pressures of some countries despite defeating most of the enemy's invasions in various areas. The occurrence of these conditions in Iran led the Supreme Leader of the country to establish a new area and literature for the continuity and national and economic authority of the country. This arena was manifested by the emergence of a concept called the resistance economy (3).

The necessity of establishing the resistance economy has been expressed in verses and narrations. God says: "and prepare against them whatever you are able of power", and we must rely on our talents and strength and lay the foundation for growth and prosperity with continuity, resistance, and continuity. The resistance economy is inviting to rely on domestic capacities and sustainable development based on potential and actual capabilities. Knowledge-based economy has been raised by the supreme leader as one of the components of the resistance economy. This concept does not mean overlooking the interaction with the world and the global economy. In fact, the knowledge-based economy emphasizes the domestic belongings and capacities in order not to leave these issues unnoticed (4).

Knowledge-based economy illustrates the role of knowledge in acquiring innovation and economic transformation and has a special place in the growth and development process. Moreover, it is one of the components of the strategies of the resistance economy extracted from the thoughts of the Supreme Leader (5). The knowledge-based economy is defined as the production of goods and services based on knowledge-sensitive activities, which increases the pace of technical and scientific progress. In addition, the key component of the knowledge-based economy is the growing reliance on intellectual capabilities and not on physical inputs or natural resources (6).

According to the literature, the knowledgebased economy is one of the features of postindustrial and global economics and is recognized as the most important approach to reduce economic vulnerability. Documents related to macroeconomic perspectives and policies of Iran also refer to the need for special attention to the knowledge-based economy in different areas (7). Along with scientific and research developments, knowledge-based economy creates a profound transformation in production and economic growth and considers long-term horizons of macro policy-making and planning in line with the realization of the resistance economy (8).

Studies show that developed economies are well prepared to take advantage of the power of knowledge. In addition to human, natural 
and social assets in these economies, the political will of their governments mainly supports knowledge-based developments. An important point is that finding a solution for sustainable development in developing countries has been put on the agenda. In practice, the nature of knowledge, especially its novelty, transferability, and subjectivity are likely to be distinguished from other sources (9).

According to Article 45 of the Law of the Fourth Program of Economic, Social and Cultural Development, the government is obliged to anticipate necessary measures and mechanisms and adopt strategies and measures to support and develop the market for knowledge-based products, commercialize research and innovative achievements, and increase the role of the private and cooperative sectors (10). University is the cradle of knowledge production and training of knowledgeable people. Today, the value creation opportunities of educational organizations are subject to the management of knowledge assets, which aim to use the intangible assets of "knowledge".

In new business environments, profitability depends on the ability to learn and adapt to the environment to a great extent (11). In addition, higher education institutions are considered as the main source for providing human capital needed for the production and translation of knowledge. Therefore, not only the design of a new model in knowledgebased economies is crucial, but also it improves the conditions for the distribution of innovation and the enhancement of coordination mechanisms and participation in innovation networks (12). Knowledge-based economic development at the university can be related to access to education, technology transfer, research, support, and domestic development. In this regard, measures such as increasing the budget, re-designing, having access to research and improving knowledge, facilitating cooperation and creating strategic and empowering links could be taken (13).

As mentioned before, the academic system is one of the main institutions in determining the quality of information based on the knowledge-based economy. In addition, the faculty members play the key role in the translation of knowledge and knowledgebased economy of the country, which realizes the resistance economy. In addition to the general mission of training specialized human resources and manufacturing technological knowledge-based products, the University of Medical Sciences has a special place with regard to its field of work and the close relationship of human health with the performance of the entire system of society. However, it seems that in this novice discussion, there is a severe lack of applied research for a variety of reasons, including the priority of health and treatment and the lack presence of any issues related to knowledgebased economies. We can explain business environments and opportunities by developing relevant studies.

Given the quantitative and qualitative extension of the subject, the present study aimed to determine the viewpoints of managers and faculty members in a university of medical sciences toward the dimensions of the resistance economy based on knowledgebased economy.

\section{Materials and Methods}

This qualitative research was conducted in Golestan University of Medical Sciences, Gorgan, Iran, and the data were collected using library and field research. In the library method, the relevant contents and books were evaluated and reviewed and information was searched on scientific and specialized websites. In this regard, articles and contexts related to the knowledge-based economy and 
resistance economy were translated, followed by designing a conceptual model based on the previous studies and applying the model in semi-structured interviews.

In this review research, all articles published on the topic of the study during 2011-2017 (2005-2017) were studied. In order to find relevant papers, some of the domestic (e.g., SID, Irandoc, Magiran) and international (e.g., Science Direct, Pubmed, and Google Scholar) were searched using Farsi and English keywords.

In the field research, semi-structured interviews were conducted with the faculty members and elites (including faculty members with a research and article production background) after the necessary coordination. This type of interview is suitable for qualitative studies due to its flexibility and in-depth nature. Considering the novelty of the topic in the field of medicine and due to the request of the interviewees, a brief explanation of the definition of the resistance economy based on the knowledge-based economy was expressed at first, followed by asking the opinion of the participants about the topic. In this regard, the questions included: "what comes to your mind when you hear the terms resistance economy and knowledge-based economy?", "In your opinion, what are the components required to realize the resistance economy based on the knowledge-based economy in the university?", "what are the necessary foundations for the realization of the knowledge-based resistance economy in the university?", and "what is the role of human resources, management, structure, and information and communication technology in this field?".

In total, 24 participants were selected in this research using purposeful sampling. Inclusion criteria included a history of knowledge production and a management background. During the interviews, the interviewees also introduced knowledgeable and competent individuals to acquire information and conduct interviews with these people on the subject. After each interview that lasted approximately 45 minutes, the recorded voices were transcribed and typed in Word software, followed by classifying and coding the texts using Microsoft OneNote. In other words, the interview processes included recording, transcribing, coding, and classifying. During the work and if required, the researcher provided feedback and referred to key elites based on the recommendation of the participants.

During the research process, ethical considerations were observed from collecting the data until the end of the analysis process of reporting the results. A written informed consent was obtained from the subjects and they were ensured of the confidentiality terms regarding their personal information. In addition, the participants were allowed to withdraw from the research at any time. Furthermore, the subjects allowed the research to record the interviews. In order to increase the acceptability of the data, the interviews were recorded and implemented immediately after the interview and the process continued until the saturation of the data. Moreover, data verification and transferability and the increase of the accuracy and reliability of the data were carried out through review by the participants as well as other elites and peers.

All interviews were classified in three stages. In addition, content validity ratio (CVR) and content validity index (CVI) were used to confirm the accessibility of the extracted dimensions. In CVR, the opinions of experts 
on contents of the dimensions and items were used, and each item was classified based on a three-point Likert scale, including "item is necessary", "item is useful but not necessary", and "item is not necessary". Considering the number of experts $(\mathrm{N}=15)$, the items with CVR estimated below 0.49 were eliminated from the research due to having an unacceptable content validity. Therefore, 40 out of 118 items remained in the end.

In CVI test, experts were asked about the "relevance", "clarity" and "simplicity" of the items based on a four-point Likert scale. In terms of relevance, experts selected an alternative of "not relevant" (score: 1), "relatively relevant" (score: 2), "relevant" (score: 3), and "completely relevant" (score: 4). On the other hand, clarity of the items was determined using four alternatives of "not clear" (score: 1), "relatively clear" (score: 2), "clear" (score: 3), "clearly linked" (score: 4). Given the fact that the mean acceptable value for CVI is 0.8 (14), the items with CVI below this value were eliminated from the research. In the end, six dimensions containing 38 items were confirmed.

\section{Results}

In general, responses were at a positive level. Demographic characteristics of the participants are presented in the table below.
Table 1. Characteristics of faculty members and managers based on gender, rank, and background

\begin{tabular}{|c|c|c|c|}
\hline Rank & History & Gender & Participant \\
\hline Instructor & 3 & Female & $\mathrm{P} 1$ \\
\hline $\begin{array}{l}\text { Associate } \\
\text { professor }\end{array}$ & 30 & Female & $\mathrm{P} 2$ \\
\hline Instructor & 5 & Male & P3 \\
\hline Instructor & 20 & Female & $\mathrm{P} 4$ \\
\hline $\begin{array}{l}\text { Associate } \\
\text { professor }\end{array}$ & 22 & Female & P5 \\
\hline Instructor & 27 & Female & P6 \\
\hline Instructor & 3 & Female & P7 \\
\hline Instructor & 2 & Male & P8 \\
\hline $\begin{array}{l}\text { Associate } \\
\text { professor }\end{array}$ & 16 & Male & P9 \\
\hline $\begin{array}{l}\text { Associate } \\
\text { professor }\end{array}$ & 8 & Female & $\mathrm{P} 10$ \\
\hline $\begin{array}{l}\text { Associate } \\
\text { professor }\end{array}$ & 22 & Male & P11 \\
\hline $\begin{array}{l}\text { Assistant } \\
\text { professor }\end{array}$ & 9 & Female & P12 \\
\hline $\begin{array}{l}\text { Assistant } \\
\text { professor }\end{array}$ & 23 & Female & P13 \\
\hline $\begin{array}{l}\text { Assistant } \\
\text { professor }\end{array}$ & 23 & Male & P14 \\
\hline $\begin{array}{l}\text { Assistant } \\
\text { professor }\end{array}$ & 4 & Male & P15 \\
\hline $\begin{array}{l}\text { Assistant } \\
\text { professor }\end{array}$ & 23 & Male & P16 \\
\hline $\begin{array}{l}\text { Associate } \\
\text { professor }\end{array}$ & 22 & Male & P17 \\
\hline $\begin{array}{l}\text { Assistant } \\
\text { professor }\end{array}$ & 19 & Male & P18 \\
\hline $\begin{array}{l}\text { Associate } \\
\text { professor }\end{array}$ & 9 & Female & P19 \\
\hline $\begin{array}{l}\text { Assistant } \\
\text { professor }\end{array}$ & 10 & Male & P20 \\
\hline $\begin{array}{l}\text { Assistant } \\
\text { professor }\end{array}$ & 12 & Female & P21 \\
\hline $\begin{array}{l}\text { Associate } \\
\text { professor }\end{array}$ & 6 & Male & P22 \\
\hline $\begin{array}{l}\text { Assistant } \\
\text { professor }\end{array}$ & 17 & Female & P23 \\
\hline Instructor & 5 & Male & $\mathrm{P} 24$ \\
\hline
\end{tabular}


Summary of some of the results related to the evaluation of contents and history of domestic and foreign studies is shown in the tables below.

Table 2. Summary of History of Domestic Research

\begin{tabular}{|c|c|c|}
\hline Authors/Year & Research Title & Research Summary \\
\hline Zakeri (2017) & $\begin{array}{l}\text { The Resistance Economy } \\
\text { and Knowledge-based } \\
\text { Economy }\end{array}$ & $\begin{array}{l}\text { The knowledge-based economy is a solution to achieve an } \\
\text { approach that not only is the essential need of the } \\
\text { developing countries, such as Iran, but also creates a } \\
\text { competitive power in the society. In addition, the } \\
\text { knowledge-based economy promotes sustainable growth } \\
\text { and development of the community and eventually } \\
\text { realizes the resistance economy. In addition, all } \\
\text { components of the knowledge-based economy have a } \\
\text { positive relationship with economic growth and } \\
\text { productivity (15). }\end{array}$ \\
\hline $\begin{array}{l}\text { Amouzadeh et al. } \\
(2017)\end{array}$ & $\begin{array}{llr}\text { Impact Model of } \\
\text { University } & \text { Education on } \\
\text { Resistance } & \text { Economy }\end{array}$ & $\begin{array}{l}\text { University has a significant effect on human resources, } \\
\text { cultural, political, social and economic infrastructures, } \\
\text { which exert impacts on the resistance economy (16). }\end{array}$ \\
\hline $\begin{array}{l}\text { Sadeghi \& } \\
\text { Mousavi (2016) }\end{array}$ & $\begin{array}{l}\text { STUDY of Vulnerable } \\
\text { Industrial Structure in } \\
\text { Iran and Prioritizing } \\
\text { Industries Based on } \\
\text { Resistance Economy }\end{array}$ & $\begin{array}{l}\text { The first priority in the implementation of the resistance } \\
\text { economy in the country's industries is to reduce the } \\
\text { dependence of industries on foreign raw materials. The } \\
\text { second priority is to strengthen the strategic industries } \\
\text { related to the basic needs of the people while the third } \\
\text { priority is to increase the training of the personnel of each } \\
\text { field of activity in order to improve the knowledge-based } \\
\text { industry (17). }\end{array}$ \\
\hline $\begin{array}{l}\text { Gorjizadeh \& } \\
\text { Sharifi (2014) }\end{array}$ & $\begin{array}{l}\text { Role of Knowledge-based } \\
\text { Economics in Controlling } \\
\text { Inflation, } \quad \text { Economic } \\
\text { Modeling }\end{array}$ & $\begin{array}{l}\text { There is a long-term relationship between all indicators of } \\
\text { knowledge-based economy and inflation. The index of } \\
\text { innovation and invention system, infrastructures of } \\
\text { information and communication technology, and } \\
\text { institutional and economic systems have a negative and } \\
\text { significant effect on inflation according to expectations. } \\
\text { The index of education and human resources development } \\
\text { has a positive and significant effect on inflation (18). }\end{array}$ \\
\hline $\begin{array}{l}\text { Khaloobagheri et } \\
\text { al. (2013) }\end{array}$ & $\begin{array}{l}\text { Facing Space Inequality } \\
\text { While Employing } \\
\text { Planning Based on } \\
\text { Improving the Quality of } \\
\text { Life, Economy and City } \\
\text { Management }\end{array}$ & $\begin{array}{l}\text { Improving the quality levels of laws and regulations and } \\
\text { protecting the security of individual property rights is one } \\
\text { of the government's priorities in raising the level of } \\
\text { knowledge-based economy in the country, so that with the } \\
\text { help of the return of researchers and the costs spent on } \\
\mathrm{R} \& \mathrm{D} \text {, we could achieve the resistance economy, which is } \\
\text { the dynamic and sustainable economy (19). }\end{array}$ \\
\hline
\end{tabular}




\begin{tabular}{|l|l|l|}
\hline $\begin{array}{l}\text { Tabarsa et al. } \\
(2012)\end{array}$ & $\begin{array}{l}\text { Designing and Explaining } \\
\text { Competitive Intelligence } \\
\text { Model Based on } \\
\text { Organizational } \\
\text { Intelligence } \\
\text { Knowledge-based in } \\
\text { Organizations }\end{array}$ & $\begin{array}{l}\text { The most important factor affecting the components of } \\
\text { knowledge strategies is the use of knowledge. In this } \\
\text { regard, the variable knowledge societies, societies with } \\
\text { common interests, the component of competitive } \\
\text { advantage, sensitivity to market and sensitivity to } \\
\text { competitors are the most important effective indexes (20). }\end{array}$ \\
\hline $\begin{array}{l}\text { Aref \& Bakhtiari } \\
(2012)\end{array}$ & $\begin{array}{l}\text { Thenessity of Turning } \\
\text { Knowledge innology and National } \\
\text { Wealth }\end{array}$ & $\begin{array}{l}\text { Production of science leads to the production of } \\
\text { technology and wealth. With planning and establishment } \\
\text { of appropriate infrastructures, it will be possible to reach } \\
\text { the technology and industry arising from the knowledge } \\
\text { within the country (21). }\end{array}$ \\
\hline Shahnazi (2012) & $\begin{array}{l}\text { Factors Affecting the } \\
\text { Manufacturing of High- } \\
\text { tech Industries in the } \\
\text { Knowledge-based } \\
\text { Economy }\end{array}$ & $\begin{array}{l}\text { Characteristics of the knowledge-based economy are } \\
\text { infrastructure and primary layer including education, } \\
\text { information and communication technology, the second } \\
\text { layer containing researchers and technicians, the third } \\
\text { layer encompassing scientific articles, unpublished } \\
\text { research and inventions, and the fourth layer comprising } \\
\text { of knowledge-based economy, namely, industries and } \\
\text { services based on knowledge (22). }\end{array}$ \\
\hline
\end{tabular}

Table 3. Summary of History of Foreign Research

\begin{tabular}{|l|l|l|}
\hline Author/Year & Research Title & Research Summary \\
\hline $\begin{array}{l}\text { Leydesdorff, } \\
\text { Etzkowitz, } \\
\text { Ivanova \& } \\
\text { Meyer (2017) }\end{array}$ & $\begin{array}{l}\text { Synergy in Innovation } \\
\text { Systems: Redundancy } \\
\text { Generation in a Triple } \\
\text { Helix of University- } \\
\text { Industry-Government } \\
\text { Relations }\end{array}$ & $\begin{array}{l}\text { The threefold relationship is effective in modeling the } \\
\text { knowledge-based economy and innovation, and its } \\
\text { structures exist in social constructions, such as scientific } \\
\text { communications and stakeholder organizations (23). }\end{array}$ \\
\hline $\begin{array}{l}\text { Lee \& Kim } \\
(2016)\end{array}$ & $\begin{array}{l}\text { Analyzing Interaction in } \\
\text { R\&D Networks Using the } \\
\text { Triple Helix Method }\end{array}$ & $\begin{array}{l}\text { The government must carefully and systematically review } \\
\text { the feedback on unwanted effects of new policies and } \\
\text { encourage R\&D networks through direct and indirect } \\
\text { policies prior to implementing regulations for R\&D } \\
\text { networks (24). }\end{array}$ \\
\hline $\begin{array}{l}\text { Dalmarco, } \\
\text { Zawislak, } \\
\text { Bulsink } \\
(2015)\end{array}$ & $\begin{array}{l}\text { How Knowledge Flows in } \\
\text { University-Industry } \\
\text { Relations }\end{array}$ & $\begin{array}{l}\text { The difference between the development of technology and } \\
\text { the knowledge infrastructures between the national and } \\
\text { private units was in innovation, and industrial companies } \\
\text { had wider partnerships with academic units (25). }\end{array}$ \\
\hline $\begin{array}{l}\text { Margaret \& } \\
\text { Kavitha } \\
(2014)\end{array}$ & $\begin{array}{l}\text { Higher Education and } \\
\text { Economic Development }\end{array}$ & $\begin{array}{l}\text { The four major missions of higher education programs that } \\
\text { lead to economic and social development are human capital } \\
\text { formation, the structure of knowledge base, dissemination } \\
\text { and use of knowledge, and knowledge preservation (13). }\end{array}$ \\
\hline
\end{tabular}




\begin{tabular}{|c|c|c|}
\hline $\begin{array}{l}\text { Tzortzaki \& } \\
\text { Mihiotis } \\
(2014)\end{array}$ & $\begin{array}{l}\text { Review of Knowledge } \\
\text { Management Theory and } \\
\text { Future Directions, } \\
\text { Knowledge and Process } \\
\text { Management }\end{array}$ & $\begin{array}{l}\text { Production of knowledge is the main capital in } \\
\text { organizational environments that largely depends on the } \\
\text { ability to learn and adapt. In this respect, the formulation of } \\
\text { rules increases productivity (11). }\end{array}$ \\
\hline $\begin{array}{l}\text { Borggren \& } \\
\text { Eriksson } \\
(2014)\end{array}$ & $\begin{array}{l}\text { Human Capital, Skills and } \\
\text { Employment Growth }\end{array}$ & $\begin{array}{l}\text { The combination of urban talent and changing skills is } \\
\text { correlated with the dynamics of employment. While human } \\
\text { capital concentrations are more beneficial the in initial } \\
\text { recovery, the combination of skills is effective in the long } \\
\text { run (26). }\end{array}$ \\
\hline $\begin{array}{l}\text { Banoa } \\
\text { Taylor } \\
(2014)\end{array}$ & $\begin{array}{l}\text { Universities and the } \\
\text { Knowledge-based } \\
\text { Economy: Perceptions } \\
\text { from a Developing } \\
\text { Country, Higher Education } \\
\text { Research \& Development }\end{array}$ & $\begin{array}{l}\text { Universities play a significant role in developing the future } \\
\text { of the country and are based on an understanding of the } \\
\text { potential economic achievements and widespread social } \\
\text { progress (27). }\end{array}$ \\
\hline Toca & \begin{tabular}{lr}
\multicolumn{2}{l}{ Knowledge-based } \\
Economy Assessment. \\
Journal of Knowledge \\
Management, Economics \\
and \\
Technology
\end{tabular} & $\begin{array}{l}\text { The knowledge-based economy is the result of economic } \\
\text { development based on knowledge. The frameworks for } \\
\text { assessing the knowledge-based economy by a number of } \\
\text { dimensions include economic incentives and governance, } \\
\text { education and human resources, the innovation system, } \\
\text { information, and communications technology (28). }\end{array}$ \\
\hline er et & $\begin{array}{l}\text { A New Model for } \\
\text { University-Industry Links } \\
\text { in Knowledge-Based } \\
\text { Economies }\end{array}$ & $\begin{array}{l}\text { Universities with collaborative communities have increased } \\
\text { the capability and suitability of the entire population, } \\
\text { increased the diversity of knowledge among companies, } \\
\text { and enhanced the distribution of innovation in terms of } \\
\text { quantity and speed (12). }\end{array}$ \\
\hline $\begin{array}{l}\text { Arml } \\
(200\end{array}$ & $\begin{array}{l}\text { Organizational Innovation: } \\
\text { the Challenge of Measuring } \\
\text { Non-technical Innovation } \\
\text { in Large-scale Surveys }\end{array}$ & $\begin{array}{l}\text { An organizational innovation involves c } \\
\text { structure and processes of an organization } \\
\text { managerial and operational concepts, such a } \\
\text { of groups in production, supply chain ma } \\
\text { quality management systems (30). }\end{array}$ \\
\hline $\begin{array}{l}\text { No } \\
(20\end{array}$ & $\begin{array}{ll}\text { A Dynamic } & \text { Theory of } \\
\text { Organizational } & \text { Knowledge } \\
\text { Creation } & \end{array}$ & $\begin{array}{l}\text { When markets change, technology increases and overflows, } \\
\text { rivals expand, and products quickly outdated, companies } \\
\text { that continuously create new knowledge in new } \\
\text { technologies and products of the organization are the ones } \\
\text { that succeed in this area (31). }\end{array}$ \\
\hline $\begin{array}{l}\text { Spender \& } \\
\text { Marr (2005) }\end{array}$ & $\begin{array}{l}\text { A Knowledge-based } \\
\text { Perspective on Intellectual } \\
\text { Capital }\end{array}$ & $\begin{array}{l}\text { The dynamic knowledge-based approach offers } \\
\text { opportunities for the development of the organization's } \\
\text { future. This systematic approach creates the value of } \\
\text { knowledge and marks the turbulent organizational reality in } \\
\text { today's world (32). }\end{array}$ \\
\hline
\end{tabular}


Results of library and field research and evaluation of texts on the resistance economy based on the knowledge-based economy were collected, and the conceptual model was explained in the table below.

Table 4. Dimensions of Knowledge-based Resistance Economy Obtained from Studies Analyzed

\begin{tabular}{|c|c|c|c|c|}
\hline $\begin{array}{lr}1) & \text { Economic } \\
\text { system } & \text { and } \\
\text { governance (Tocan, } \\
2011 \text { and } \\
\text { Tzortzaki, 2011) }\end{array}$ & $\begin{array}{l}\text { 2) Education and } \\
\text { research (Sadeghi } \\
\& \text { Mousavi, 2016 } \\
\text { and Margaret \& } \\
\text { Kavitha, 2014). }\end{array}$ & $\begin{array}{l}\text { 3) Information and } \\
\text { communications } \\
\text { infrastructures } \\
\text { (Shahnazi, 2012 } \\
\text { and Tocan, 2012). }\end{array}$ & $\begin{array}{l}\text { 4) Innovation and } \\
\text { inventions system } \\
\text { (Lowchen, } 2010 \text { and } \\
\text { Lidsorf, } 2017 \text { and } \\
\text { Tocan 2012). }\end{array}$ & $\begin{array}{l}\text { 5) Capabilities } \\
\text { and Features } \\
\text { (Armbruster, } \\
2008 \text { and } \\
\text { Niknam, 2017) }\end{array}$ \\
\hline $\begin{array}{l}\text { The economic and } \\
\text { governance system } \\
\text { of the country } \\
\text { provides incentives } \\
\text { for the optimal use } \\
\text { of the existing and } \\
\text { new knowledge } \\
\text { and } \\
\text { entrepreneurship } \\
\text { flourish. }\end{array}$ & $\begin{array}{l}\text { Skilled manpower } \\
\text { working with the } \\
\text { research, } \\
\text { education, and } \\
\text { skills that } \\
\text { empower them. }\end{array}$ & $\begin{array}{l}\text { Dynamic } \\
\text { information } \\
\text { infrastructure is } \\
\text { required } \\
\text { facilitate } \\
\text { communications } \\
\text { and publication and } \\
\text { acquisition } \\
\text { information. }\end{array}$ & $\begin{array}{l}\text { The innovation and } \\
\text { inventions system } \\
\text { must be able to } \\
\text { exploit the growing } \\
\text { knowledge storage } \\
\text { and create new } \\
\text { technologies. }\end{array}$ & $\begin{array}{l}\text { In a knowledge- } \\
\text { based resistance } \\
\text { economy, it is } \\
\text { essential to rely } \\
\text { on knowledge } \\
\text { and domestic } \\
\text { capacity for } \\
\text { development. }\end{array}$ \\
\hline
\end{tabular}

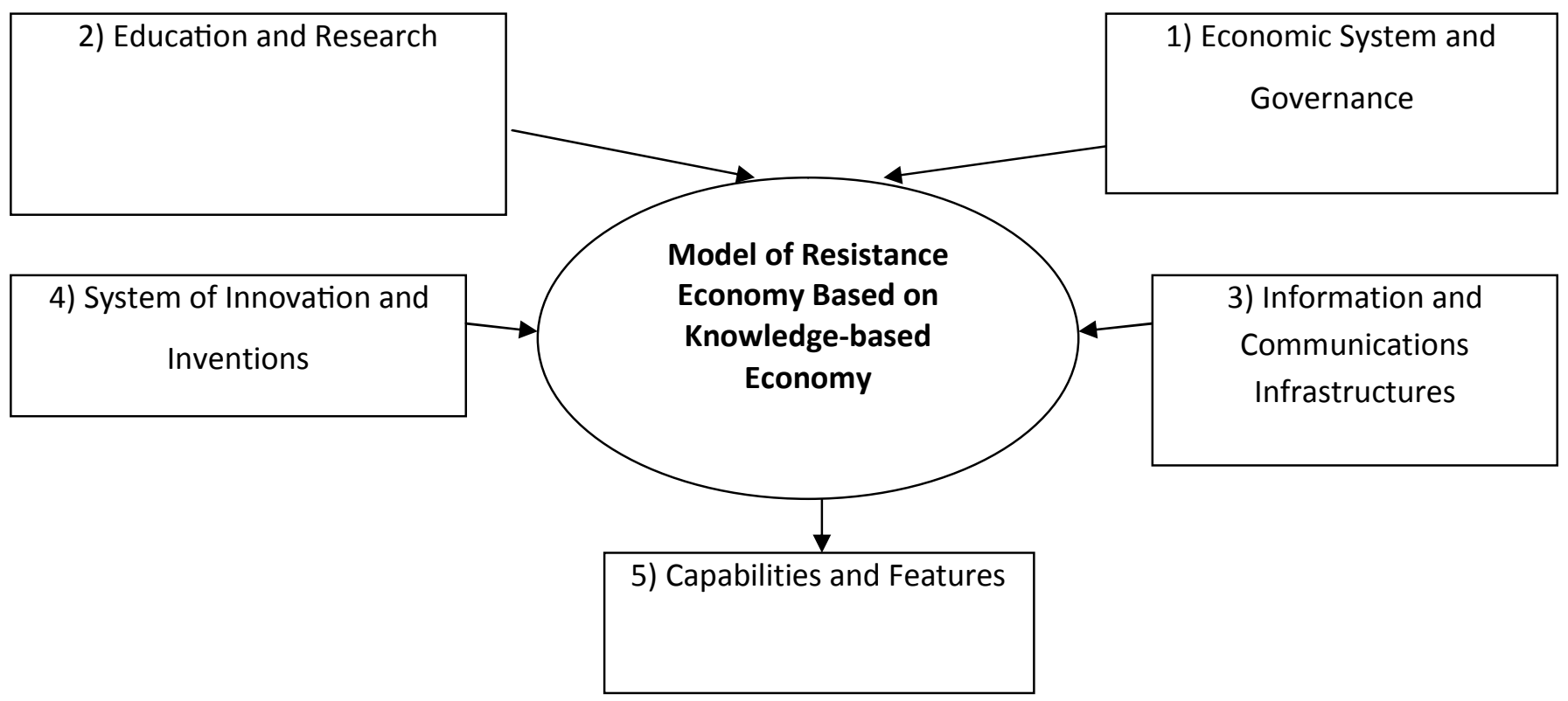




\section{Components of the Conceptual Model Based on Results Obtained from the Background Research}

In addition, results of the qualitative section extracted from interviews with elites were classified and codes and the resistance economy based on the knowledge-based economy was extracted from the opinions of the faculty members and the key experts participating in the study, as presented in the table below.

Table 5. Dimensions of Resistance Economy Based on Knowledge-based Economy in the University of Medical Sciences; the Viewpoints of Managers and Faculty Members

\begin{tabular}{|c|c|c|c|}
\hline Row & $\begin{array}{l}\text { Dimensions } \\
\text { (general } \\
\text { categories) }\end{array}$ & $\begin{array}{l}\text { Subclass (axial themes } \\
\text { and categories) }\end{array}$ & An example of statements of the participants \\
\hline \multirow[t]{5}{*}{1} & \multirow{5}{*}{$\begin{array}{l}\text { Informatio } \\
\text { n and } \\
\text { communica } \\
\text { tions } \\
\text { technology }\end{array}$} & $\begin{array}{l}\text { 1. Knowledge-based } \\
\text { database }\end{array}$ & $\begin{array}{l}\text { "There must be a knowledge-based database } \\
\text { containing projects and articles in the university." }\end{array}$ \\
\hline & & $\begin{array}{l}\text { 2. Access to online } \\
\text { technological networks }\end{array}$ & $\begin{array}{l}\text { "We must have a database with all ongoing and } \\
\text { completed projects of the university that can be } \\
\text { found based on their field." }\end{array}$ \\
\hline & & $\begin{array}{l}\text { 3. Automation and } \\
\text { internet quality }\end{array}$ & $\begin{array}{l}\text { "We must have access to the internet, especially to } \\
\text { social media since they contain good information." }\end{array}$ \\
\hline & & $\begin{array}{l}\text { 4. Online documentation } \\
\text { center }\end{array}$ & $\begin{array}{l}\text { "Establishing a system of reference books, articles, } \\
\text { and publications that is available 24/7." }\end{array}$ \\
\hline & & $\begin{array}{l}\text { 5. Knowledge-based } \\
\text { health recording systems }\end{array}$ & $\begin{array}{l}\text { "Establishing a research registration system based } \\
\text { on the needs and a disease is important for } \\
\text { improving the quality of the services." }\end{array}$ \\
\hline \multirow[t]{4}{*}{2} & \multirow{4}{*}{$\begin{array}{l}\text { Innovation } \\
\text { and } \\
\text { entreprene } \\
\text { urship in } \\
\text { medical } \\
\text { sciences }\end{array}$} & $\begin{array}{l}\text { 1. Knowledge-based } \\
\text { entrepreneurship }\end{array}$ & $\begin{array}{l}\text { "We must use knowledge to act as entrepreneurs. } \\
\text { Its impact must be recognized and be turned into a } \\
\text { product in the factory." }\end{array}$ \\
\hline & & $\begin{array}{l}\text { 2. Technological research } \\
\text { and science centers and } \\
\text { units }\end{array}$ & $\begin{array}{l}\text { "Issues that have an economic approach and are } \\
\text { based on technological knowledge must be created } \\
\text { and developed in the growth center or research } \\
\text { centers." }\end{array}$ \\
\hline & & $\begin{array}{l}\text { 3. Inventions, patents, } \\
\text { and design of health } \\
\text { systems }\end{array}$ & $\begin{array}{l}\text { "In a university of medical sciences, providing a } \\
\text { good education and a new method, modifying a } \\
\text { service and running it, producing a product or } \\
\text { discovering a gene, or recording a scientific event } \\
\text { and a disease and an epidemic or a plant can make } \\
\text { knowledge economical." }\end{array}$ \\
\hline & & $\begin{array}{lr}4 . & \text { Knowledge-based } \\
\text { applied } & \text { education } \\
\text { research } & \end{array}$ & $\begin{array}{l}\text { "In fact, we must revise the education so that it } \\
\text { could lead to science production and provision of } \\
\text { the job market." }\end{array}$ \\
\hline
\end{tabular}




\begin{tabular}{|c|c|c|c|}
\hline \multirow[t]{5}{*}{3} & \multirow[t]{5}{*}{$\begin{array}{l}\text { Knowledge- } \\
\text { based team } \\
\text { and human } \\
\text { resources }\end{array}$} & $\begin{array}{l}\text { 1. Empowering and skill } \\
\text { training }\end{array}$ & $\begin{array}{l}\text { "A manpower with the capabilities necessary to } \\
\text { participate in scientific competitions and the } \\
\text { capabilities needed to produce products that can } \\
\text { compete with foreign products." }\end{array}$ \\
\hline & & 2. Education in research & $\begin{array}{l}\text { "Research must be institutionalized in the student's } \\
\text { curriculum from the early years of education. There } \\
\text { must be some general credits taught in universities } \\
\text { and even in schools." }\end{array}$ \\
\hline & & $\begin{array}{l}\text { 3. Team approach and } \\
\text { scientific Basij }\end{array}$ & $\begin{array}{l}\text { "Attempts made as a team that is expert, } \\
\text { experienced, encouraging, supportive, and } \\
\text { guaranteeing. An attempt that leads to the final } \\
\text { product." }\end{array}$ \\
\hline & & 4. Motivation & $\begin{array}{l}\text { "We must have those who have no specific roles but } \\
\text { encourage others with high IQ so that they could } \\
\text { grow." }\end{array}$ \\
\hline & & $\begin{array}{l}\text { 5. The attraction of } \\
\text { competent and expert } \\
\text { workforce }\end{array}$ & $\begin{array}{l}\text { "Elites must be recognized and brilliant talents } \\
\text { must be nurtured and preserved so that the accurate } \\
\text { and proper human resource is attracted." }\end{array}$ \\
\hline \multirow[t]{4}{*}{4} & \multirow{4}{*}{$\begin{array}{l}\text { Manageme } \\
\text { nt system } \\
\text { and } \\
\text { structure }\end{array}$} & $\begin{array}{l}\text { 1. Dynamic knowledge- } \\
\text { based processes and } \\
\text { structure }\end{array}$ & $\begin{array}{l}\text { "The issue is the structure of our minds which } \\
\text { needs modification. }\end{array}$ \\
\hline & & $\begin{array}{l}2 . \quad \text { Regulations and } \\
\text { instructions of the } \\
\text { knowledge-based } \\
\text { resistance economy }\end{array}$ & $\begin{array}{l}\text { "There must be transparency in contracts. If two } \\
\text { people collaborate, the type of their cooperation and } \\
\text { commitment must be legally and religiously clear." }\end{array}$ \\
\hline & & $\begin{array}{l}\text { 3. Investment and } \\
\text { economic management } \\
\text { based on knowledge }\end{array}$ & $\begin{array}{l}\text { "We must reach an acceptable level in our } \\
\text { expertise and productions and then we can invest in } \\
\text { other items. We must realize that our policies must } \\
\text { be based on expertise and specialization." }\end{array}$ \\
\hline & & $\begin{array}{l}\text { 4. Facilitators and } \\
\text { catalysts }\end{array}$ & $\begin{array}{l}\text { "We must lay the proper foundation for economic } \\
\text { and domestic products based on knowledge. The } \\
\text { parliament must allocate the necessary funds, and } \\
\text { government offices and organizations must properly } \\
\text { cooperate with knowledge-based companies. In } \\
\text { general, the path to reach a healthy knowledge- } \\
\text { based economy in the country must be paved." }\end{array}$ \\
\hline \multirow[t]{2}{*}{5} & \multirow[t]{2}{*}{$\begin{array}{l}\text { Resources, } \\
\text { capabilities, } \\
\text { and features }\end{array}$} & $\begin{array}{l}\text { 1. Provision of capital } \\
\text { based on technological } \\
\text { knowledge }\end{array}$ & $\begin{array}{l}\text { "When we talk about cost-benefit, handouts are the } \\
\text { criteria. The issue is that we pay to create benefits } \\
\text { for people. A part of this concept is cost- } \\
\text { effectiveness. }\end{array}$ \\
\hline & & $\begin{array}{l}\text { 2. Raising funds based on } \\
\text { regional features and } \\
\text { capabilities }\end{array}$ & $\begin{array}{l}\text { "Knowledge-based companies must be established } \\
\text { based on regional local benefits in terms of plant } \\
\text { and animal diversity. Golestan province has good } \\
\text { agricultural land and favorable climate and can use } \\
\text { these features." }\end{array}$ \\
\hline
\end{tabular}




\begin{tabular}{|c|c|c|c|}
\hline & & $\begin{array}{l}3 . \quad \text { Support } \quad \text { of } \\
\text { commercialization of } \\
\text { medical knowledge-based } \\
\text { centers }\end{array}$ & $\begin{array}{l}\text { "One of the issues that must be taught is how to } \\
\text { establish a company (Park) and how to invest and } \\
\text { receive loans in order to turn works into products." }\end{array}$ \\
\hline & & $\begin{array}{l}\text { 4. Domestic capacities } \\
\text { and abilities in the health } \\
\text { area }\end{array}$ & $\begin{array}{l}\text { "Considering the domestic advantages of the } \\
\text { region could play an important role in the education } \\
\text { of graduate students along with skill training and } \\
\text { promoting university education." }\end{array}$ \\
\hline \multirow[t]{5}{*}{6} & \multirow[t]{5}{*}{$\begin{array}{l}\text { General } \\
\text { policies }\end{array}$} & $\begin{array}{l}\text { 1. Improving the } \\
\text { scientific position based } \\
\text { on ethics }\end{array}$ & $\begin{array}{l}\text { "Observing ethical issues in a knowledge-based } \\
\text { economy is crucial. We can improve our global } \\
\text { position in the area of science and technology by } \\
\text { producing knowledge in the field of medicine based } \\
\text { on knowledge." }\end{array}$ \\
\hline & & $\begin{array}{l}2 . \quad \text { Optimizing the } \\
\text { research system based on } \\
\text { translation and } \\
\text { knowledge management }\end{array}$ & $\begin{array}{l}\text { "Production of science, development of innovation } \\
\text { and theorizing, and promotion of knowledge } \\
\text { translate approach must be in line with increasing } \\
\text { the productivity of research and technology } \\
\text { products." }\end{array}$ \\
\hline & & $\begin{array}{l}\text { 3. The evolution of higher } \\
\text { education }\end{array}$ & $\begin{array}{l}\text { "In this type of economy, our country seeks an ideal } \\
\text { economy that is both Islamic and is able to reach us } \\
\text { to the first regional economy status. It means that } \\
\text { higher education must be evolved and universities } \\
\text { must move toward the third generation and } \\
\text { entrepreneurship." }\end{array}$ \\
\hline & & $\begin{array}{l}\text { 4. Development of } \\
\text { research in the health area }\end{array}$ & $\begin{array}{l}\text { "In the University of Medical Sciences, } \\
\text { development of research and patents can make } \\
\text { knowledge economic." }\end{array}$ \\
\hline & & $\begin{array}{l}5 . \quad \text { Design, } \\
\text { implementation, and } \\
\text { evaluation of the result of } \\
\text { the knowledge-based } \\
\text { resistance economy }\end{array}$ & $\begin{array}{l}\text { "We must carry out our design based on the } \\
\text { condition of the community. If you are not Einstein, } \\
\text { recruit an Einstein. We hire elites to tell us what to } \\
\text { do (trait owners). At the beginning of the designing } \\
\text { process, we must carry out proper assessments. } \\
\text { After allocating a budget to the project, accurate } \\
\text { monitoring must be based on the protocol to } \\
\text { determine whether there is progress in the work or } \\
\text { not (quality of the claim made). After that, we can } \\
\text { recruit marketing experts. By doing so, we } \\
\text { financially and spiritually support the government." }\end{array}$ \\
\hline 7 & $\begin{array}{l}\text { Socio- } \\
\text { environmen } \\
\text { tal effects }\end{array}$ & $\begin{array}{l}\text { 1. Proper environmental } \\
\text { knowledge-based } \\
\text { opportunities }\end{array}$ & $\begin{array}{l}\text { "Golestan province has fertile agricultural lands } \\
\text { and favorable climate for agriculture and can use } \\
\text { these advantages for establishing a knowledge- } \\
\text { based resistance economy." }\end{array}$ \\
\hline
\end{tabular}




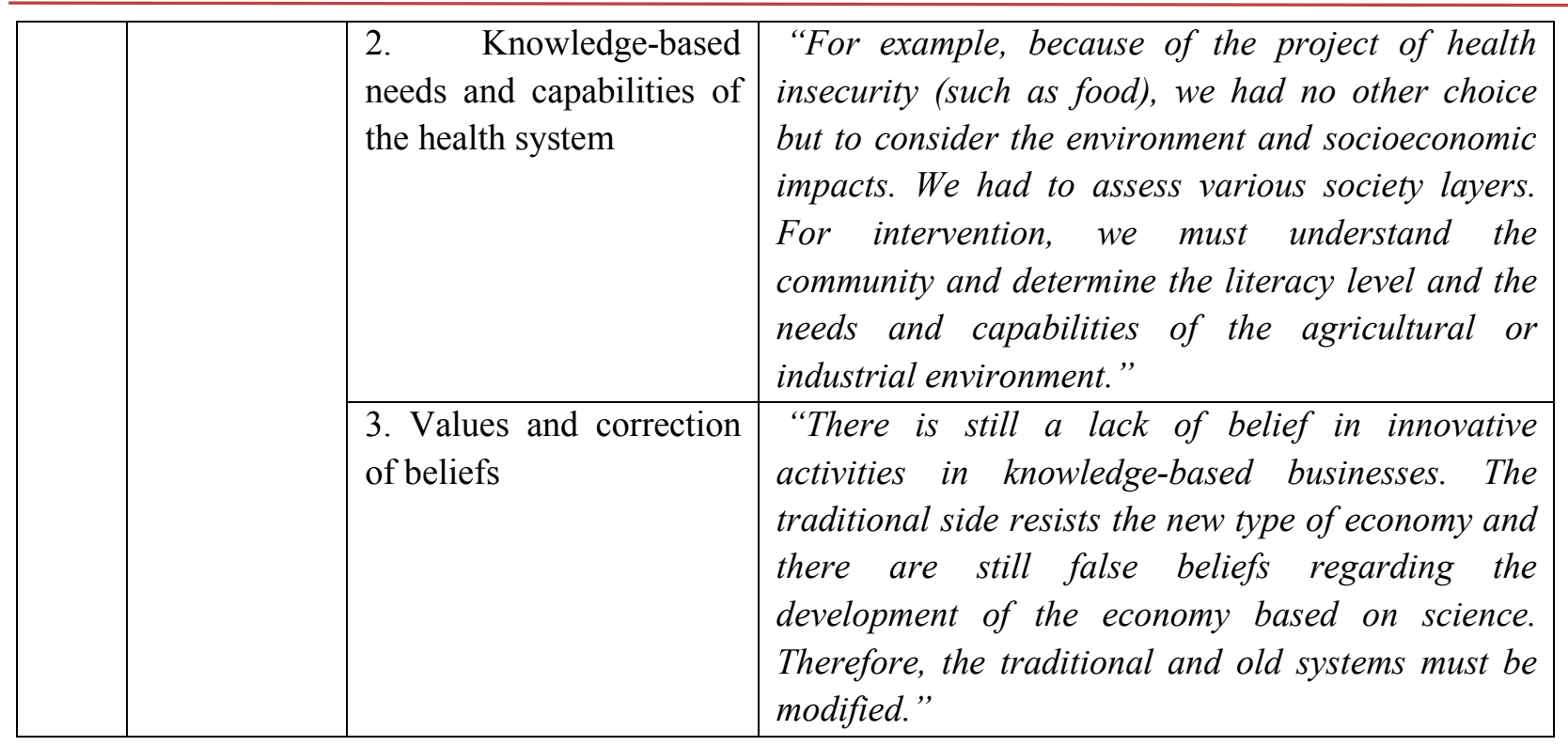

According to the table, the faculty members and key experts believed that the resistance economy based on knowledge-based economy in the University of Medical Sciences can be explained by the dimensions and areas of information and communications technology, innovation and entrepreneurship in medical sciences, knowledge-based team and human resources, administrative and structural system, resources of capabilities and features, general policies and socioenvironmental effects. This type of economy includes the themes of knowledge-based database, access to technological online knowledge networks, internet and automation quality, online documentation center, knowledge-based health systems, knowledgebased entrepreneurship, technological research and science centers and units, inventions, patents and projects of health systems, knowledge-based applied education research, empowering and skill training, education in research, team approach and scientific Basij, motivation, attraction of a competent and elite manpower, dynamic knowledge-based structures and approaches, rules and guidelines for knowledge-based resistance economy, economic investment and management based on knowledge, facilitators and catalysts, providing capital based on technological knowledge, fundraising based on regional capabilities and features, supporting the commercialization of knowledge-based medical centers, domestic capacities and abilities of health area, improving the scientific position based on ethics, optimizing the research system based on the translation and management of knowledge, the evolution of higher education, the development of research in the field of health, design, implementation and evaluation of the result of knowledge-based resistance economy, appropriate knowledge-based environmental opportunities, knowledgebased needs and capabilities of the health system, and values and modification of beliefs.

\section{Discussion}

According to the results obtained from the research in the literature and interviews conducted with the participants, it was demonstrated that the resistance economy based on knowledge-based economy would be explained in the dimensions and areas of information and communications technology, 
innovation and entrepreneurship in medical sciences, knowledge-based team and human resources, resources and capabilities, general policies, and socio-environmental effects.

In a research by Sadeghi \& Mousavi (2016) entitled "Study of Vulnerable Industrial Structure in Iran and Prioritizing Industries Based on Resistance Economy", it was demonstrated that the first priority in implementing the resistance economy in the country's industries is to reduce the dependence of industries on foreign raw materials. The second priority was of strengthening the strategic industries related to the basic needs of the people, whereas the third priority involved increasing the education level of the personnel of each industry in line with strengthening the knowledge-based industry (17). These findings are in line with the indexes of knowledge-based practical training research, increase of facilities and support of knowledge-based units, and attention to the current capacities of the research. Therefore, in the knowledge-based resistance economy, one of the priorities is developing studies related to knowledge in line with the needs of the society members.

In a study by Gorjizadeh et al. (2014) entitled "The Role of Knowledge-based Economics in Controlling Inflation, Economic Modeling", the axes of the knowledge-based economy were reported to be economic and institutional regimes, human resource education and development, infrastructures of information and communications technology, and innovation and inventions system (18), which in congruence with the present study in terms of the dimensions of information and communications technology, innovation and entrepreneurship in medical sciences, knowledge-based team and human resources, and resources and facilities. Therefore, it could be concluded that focusing on the optimal use of resources of a knowledgebased economy and knowledge infrastructures is, in fact, providing a modern approach to realize the resistance economy, as well as national production and entrepreneurship.

According to the results obtained by Khaloobagheri et al. (2013) in a research entitled "Facing Space Inequality While Employing Planning Based on Improving the Quality of Life, Economy and City Management", focusing on the promotion of the level and quality of laws and regulations and establishing laws that protect the security of individual property rights are among the government's priorities to raise the level of knowledge-based economy in the country (19). In the present study, formulating rules and policies and a management system in line with the knowledge-based resistance economy was expressed as one of the dimensions. In this regard, a collaboration of universities with the industry and legal infrastructures for support of knowledgebased companies must be predicted, approved, and implemented in government regulations and policy references.

In a research by Azizi (2013) entitled "Study Ways to Improve Faculty Members' Research Performance in Humanities, Culture Strategy", it was shown that improving the performance of faculty members requires correcting the organizational approaches and research policy-making and management from one hand and implementing empowering programs and strengthening the professional abilities of professors in research area and providing the proper financial, material, and scientific resources and conditions for 
research activities of professors from the other hand (33). These results are consistent with our findings regarding the indexes of attention to the current capabilities and capacities, development of research, regulations, and instructions of the knowledge-based resistance economy, the formation of facilitators, education in research, empowering and skill training, applied knowledge-based education research, and increased facilities and support. According to the results of the study, it is possible to emphasize applied research and the facilitation and encouragement of the use of knowledge-based economies in the research process of the resistance economy and economic development.

In a study by Aref and Kiani (2012) entitled "the Necessity of Turning Knowledge into Technology and National Wealth", it was demonstrated that science production led to the creation of technology and wealth. However, reaching technology and industry emerged from knowledge will not be possible in the country without planning and establishing the proper infrastructures (21). In this regard, our findings are in accordance with the results obtained from the mentioned study regarding the dimensions of technology and infrastructures of the knowledge-based resistance economy, communication links, and knowledge-based products. Therefore, we can take effective steps toward the qualitative and quantitative growth of the country by establishing knowledge-based businesses. In addition, knowledge-based businesses can find their actual place in the work market and economy if the necessary support is provided.

In another research by Shahnazi (2012) entitled "Factors Affecting Manufacturing of Superior Technology in Knowledge-based Economy", it was claimed that the characteristics of the knowledge-based economy are manifested in the four main layers of the infrastructural layer, researchers and technicians, scientific articles and inventions, and knowledge-based industries and services (22). In this respect, the results obtained by Shahnazi are in line with our findings in terms of human resources, knowledge-based products, as well as structure and processes. The information infrastructures are the underlying foundation of a knowledge-based economy, which can effectively facilitate information processes and acquisition and dissemination of knowledge and increase productivity and economic growth. On the other hand, having a trained and skilled workforce in this process is one of the essential needs of the society to create, gain, publish and use knowledge. Therefore, an environment can be created in which the research and development section can be flourished, which leads to improved economic growth and productivity.

According to the results obtained by Dalmarco, Zawislak, Hulsink \& Brambilla (2015) in a research entitled "How Knowledge Flows in University-Industry Relations", the development of technology and knowledge infrastructures in research is important (25), which is in congruence with our findings regarding the areas of innovation and technology and creating and developing research infrastructures.

In a study by Banoa \& Taylor (2014) entitled "Universities and Knowledge-based Economy", it was claimed that universities play a crucial role in the development of the future of a country. In fact, the knowledgebased economy is considered as an opportunity to compete in a competitive field (27), which is consistent with our findings in terms of the effective role of universities in the realization of the resistance economy 
based on the knowledge-based economy from the perspective of faculty members and researchers. It could be expressed that universities regard the development of a knowledge-based resistance economy as the main mission. In this regard, they move towards the realization of the resistance economy based on the knowledge-based economy and dedicate efforts to value creating and entrepreneurship by modeling the top and successful universities of the world and by following the high-level documents, the national vision plan, and the comprehensive roadmap.

In a research by Ahrweiler et al. (2011) entitled "A New Model for UniversityIndustry Links in Knowledge-Based Economies", it was demonstrated that in designing a new model for linking the university and industry in knowledge-based economy, having universities with cooperating and collaborative communities will increase the level of competence, increase the diversity of knowledge among companies and enhance the distribution of innovation in terms of quantity and space. In addition, the link of universities to the industry will result in an improved condition of innovation distribution and increased collaborative mechanisms in the innovation networks (12), which is in congruence with the dimensions of human resources and creating knowledge-based teams, innovation and information, and communications technology in the current research. However, more attention must be paid to the issue of collaboration between universities and the industry section so that the creative workforce of the society is able to improve the economy of the country by using the modern technologies and producing and exporting knowledge using the capital and experience of industrialists, enhancing the economy and knowledge-based resistance economy in the country.

In today's complex competitive environment, organizations are moving towards perfectionism. Educational organizations should also manage and promote their programs and activities in accordance with their economic knowledge-based conditions, economic capacities, and economic policies and in line with the global level. Therefore, recent approaches in universities, and especially in the University of Medical Sciences, have shown that the university, while maintaining and improving its educational and research quality, can be effective in solving community problems, including economic issues and employment, and play a more active role in sustainable economic development of knowledge-based resistance economy. As such, it is suggested that the proper foundation be laid and attention be paid to the required and applied fields in medicine. In addition, it is important to acquire value from knowledge and technology and research findings and webbased training and entrepreneurial activities as a part of the mission of knowledge-based resistance economy.

\section{Conclusion}

According to the results of the present research, resistance economy based on knowledge-based economy can be institutionalized through team participation and management of knowledge-based economy, creating facilities and providing the necessary platforms for entrepreneurship and innovation and technology, strengthening and honoring intellectual and human capitals, expanding knowledge-based and technological cooperation, strategic planning 
and policy-making, formulating and ensuring the legal framework and legal system, supplying and developing electronic infrastructures and technological knowledge, and focusing on capabilities and features.

\section{Acknowledgements}

Hereby, we extend our gratitude to the faculty members and researchers of Golestan University of Medical Sciences, as well as organizations and researchers for assisting us in conducting this research.

\section{Declarations}

\section{Funding source(s)}

This article was extracted from a $\mathrm{PhD}$ dissertation on educational management approved by Islamic Azad University, Gorgan Branch (date of approval: 09/05/2016).

\section{Ethics approvals and consent to participate}

Code of Ethics:

\section{Conflict of interest}

We declare that we have no financial or nonfinancial conflicts of interest related to the subject matter or materials discussed in the article.

\section{Authors' contributions}

All authors contributed equally to this work.

\section{References}

1. Kazemi S. Intellectual wealth and creativity, Prospect of successful organizations, First Ed, Alimnoor,2015 (Persian).

2. Kazemi Sh. Presenting the model Resistance economy based on Knowledge-based economy in the University of Medical Sciences, PhD thesis2016 (Persian).

3. Idelkhani Y, Akhavan P, Hosnavi R. Combined model of knowledge management and Economic Strength, crisis management. 2016:65-76 (Persian).

4. Seifloo S, Concept of Resistance economy, 1ST ed, 2012: 151-173 (Persian).

5. Deputy of Budget and planning of Ferdowsi University, Resistive Economy and the role of universities in making it happen, 2014;53; 1-5 (Persian).

6. Powell, W., \& Snellman, K. (2004). The knowledge economy. Annual Review of Sociology, 30 (1), 199-220.

7. Homafar M, Pourjafar M. Explaining the role of urban planning in realizing the objectives of resistance economy in the field of knowledge economy, Case Study: Tehran, First International Conference on Urban Economics. 2016 (Persian).

8. Jafari A, Jafari $\mathrm{H}$. Investigation of effective social factors of students' lifestyle in relation to resistance economics; National Congress on Lifestyle Role in Resistance, Alborz University Jihad. 2013: 1-7 (Persian).

9. Chua, A.Y.K., \& Goh, D.H. Untying the knot of knowledge management measurement: A study of six public service agencies in Singapore. Journal of Information Science, 2008; 34(3): 259274.

10. Esmaeilzade H, Doshmangir L, Fatemi N, Commercialization in Research,1st ed, Tehran, Ayandeh Pajooh, 2015(Persian).

11.Tzortzaki, AM and Mihiotis, A.A Review of Knowledge Management Theory and Future Directions, Knowledge and Process Management, Volume 21 Number 1, 2014; pp :29-41. 
12.Ahrweiler, P. Pyka, A. \& Gilbert, N., A New Model for University-Industry Links in Knowledge-Based Economies, J PROD INNOV MANAG; 28, 2011; Pp. 218-235.

13.Margaret, E \& Kavitha N. V. Higher Education and Economic Development - Perspective and Prospects, Literacy Information and Computer Education Journal (LICEJ), Volume 5, Issue 1, March 2014, Pp: 1364-1368.

14. Hajizadeh A, Asqari M., Methods and statistical analyzes by looking at the research method in the biological sciences and health sciences. Jahad University Press ,1st ed, 2011(Persian)

15. Zakeri M., Resistance Economics and Knowledge Economy, National Conference on New Research in Management, Economics and Humanities, 2017, Pp:1-30 (Persian)

16. Amoozadeh J, Falah V, Safarian S., Presenting Impact Model of University Education on Resistance Economics due to the Role of Cultural Infrastructure, Human Resources, political, social and Economics, Journal of Marine Science Education, 2017, Pp:17-32 (Persian)

17. Sadeghi M, Mousavi SM, Study of vulnerable industrial structure in Iran and prioritizing industries based on resistance economy, Critical Review of Human Sciences Texts and Programs, Research Institute of Humanities and Cultural Studies of Resistance Economics. 2016, Pp:83101 (Persian)

18. Gorjizadeh A, SHarifi A. The role of knowledge-based economics in controlling inflation, economic modeling. 2014, Pp:107-125 (Persian)

19.Khaloobagheri M, Facing Space Inequality while Employing planning based on improving the quality of life, economy and city management, 2011;1(1):49-67 (Persian).

20. Tabarsa GH, Rezaiian A, Nazarpouri A, Designing and explaining a competitive intelligence model based on organizational intelligence in knowledge based organizations, Executive Management Research,2012, Pp:37-58 (Persian)
21.Aref MR, Kianibakhtiari A, the necessity of turning knowledge into technology and national wealth, volume 1, 3rd ed, Nasha elm, 2012(Persian).

22.Shahnazi R, Factors affecting manufacturing of superior technology in knowledge-based economy (Panel data Approach GLS method), Quarterly of Parks and growth centers, 2011; 9(33) (Persian).

23.Leydesdorff, L., \& Etzkowitz, H. Ivanova, I. \& Meyer, M. The Measurement of Synergy in Innovation Systems: Redundancy Generation in a Triple Helix of University-Industry-Government Relations. SPRU Working Paper Series, May 2017.

24.Lee,Young Hoon, Kim,YoungJun. Analyzing interaction in R\&D networks using the Triple Helix method: Evidence from industrial R\&D programs in Korean government. Technological Forecasting and Social Change,2016,Volume 110, Pp 93-105.

25.Dalmarco, G., Zawislak, P. A., Hulsink, W., \& Brambilla, F. How knowledge flows in universityindustry relations: An overview from two economic sectors in Brazil. European Business Review, 2015, 27(2), Pp.148-160.

26.Borggren, J \& Eriksson, R. Human Capital, Skills, and Uneven Intraurban Employment Growth: The Case of Göteborg, Sweden, 1990 2008, Volume 2014, Article ID 260813, Pp:1-14.

27- Banoa, Sh \& Taylor, J. Universities and the knowledge based economy: perceptions from a developing country, Higher Education Research \& Development, 2014; Pp: 1-16. Available from : http://www.tandfonline.com.

28. Tocan, Madalina Cristina. Knowledge Based Economy Assessment. Journal of Knowledge Management, Economics and Information Technology, 2012, Issue 5, Pp:199-212.

29.Lu, T. \& Chen, J. Incremental or radical? a study of organizational innovation: an artificial world approach, Expert Systems with Applications, 2010, 37(14), 8193-8200.

30.Armbruster, H. Organizational innovation: the challenge of measuring non-technical innovation 
in large-scale surveys, Technovation, 2008, 28(7), Pp: 644-657.

31.Nonaka I. (2007). A dynamic theory of organizational knowledge creation. Organization Science 5(1), pp:14-37.

32.Spender JC, Marr B. A knowledge-based perspective on intellectual capital. In Perspectives on Intellectual Capital' 2005, Marr B (ed.). Sage; 183-195.

33. Azizi N, study ways to improve faculty members' research performance in humanities, culture strategy. 2013, Pp:7-34 (Persian)

\section{How to cite:}

Kazemi Malek Mahmoudi Sh, Niaz Azari K, Jabari N. Explaining the Aspects of Resistance Economy Based on Knowledge-based Economy in University of Medical Sciences: The Viewpoints of Managers and Faculty Members.

Jorjani Biomedicine Journal. 2018; 6(2): 76-94. DOI: 10.29252/jorjanibiomedj.6.2.77 